\title{
Genome-wide association study identifies loci influencing natural antibody titers in milk of Dutch Holstein-Friesian cattle
}

\author{
Juan Cordero-Solorzano, ${ }^{1,2}$ Henk K. Parmentier, ${ }^{3}$ Joop A. J. Arts, ${ }^{3}$ Jan van der Poel, ${ }^{2}$ Dirk Jan de Koning, ${ }^{1}$ \\ and Henk Bovenhuis ${ }^{2 *}$ \\ ${ }^{1}$ Swedish University of Agricultural Sciences, Department of Animal Breeding and Genetics, Box 7023,750 07, Uppsala, Sweden \\ ${ }^{2}$ Wageningen University and Research, Animal Breeding and Genomics, PO Box 338, $6700 \mathrm{AH}$, Wageningen, the Netherlands \\ ${ }^{3}$ Wageningen University and Research, Adaptation Physiology Group, PO Box 338, $6700 \mathrm{AH}$, Wageningen, the Netherlands
}

\section{ABSTRACT}

Natural antibodies (NAb) are produced without any antigenic stimulation as a part of the innate immune system and provide a first line of defense against pathogens. Hence, they may be a useful trait when estimating an animal's potential immune competence and in selection for disease resistance. The aim of this study was to identify genomic regions associated with different $\mathrm{NAb}$ traits in milk and potentially describe candidate genes. Milk samples from 1,695 first-lactation Holstein Friesian cows with titer measurements for keyhole limpet hemocyanin, lipopolysaccharide, lipoteichoic acid, and peptidoglycan-binding total $\mathrm{NAb}$ and isotypes $\operatorname{IgG}_{1}$, IgM, and IgA were used. Genome-wide association study analyses were performed using imputed 777K SNP genotypes, accounting for relationships using pedigree information. Functional enrichment analysis was performed on the significantly associated genomic regions to look for candidate genes. For IgM NAb, significant associations (false discovery rate $<0.05$ ) were found on Bos taurus autosome (BTA) 17, 18, and 21 with candidate genes related to immunoglobulin structure and early $\mathrm{B}$ cell development. For $\mathrm{IgG}_{1}$, associations were found on BTA3, and we confirmed a quantitative trait loci on BTA21 previously reported for IgG NAb in serum. Our results provide new insights into the regulation of milk NAb that will help unravel the complex relationship between milk immunoglobulins and disease resistance in dairy cattle.

Key words: natural antibody, dairy cattle, genomewide association study, immunoglobulin

\section{INTRODUCTION}

Breeding for improved health is a current challenge in dairy cattle. Health-related problems constitute an

Received March 15, 2019.

Accepted August 5, 2019.

*Corresponding author: henk.bovenhuis@wur.nl important economic and welfare issue that has gained more attention in recent years. Breeding programs have started to include traits such as clinical mastitis and hoof health parameters (Heringstad et al., 2018). Currently, however, no traits reflect general disease resistance or immune response. For such purposes, natural antibodies (NAb) might be a good candidate trait.

Natural antibodies in dairy cattle have been associated with risk of mastitis (Thompson-Crispi et al., 2013), length of productive life (de Klerk, 2016), lameness (Denholm et al., 2018), and postpartum uterine health (Machado et al., 2014). In other species such as chickens, serum NAb have been linked to survival (Star et al., 2007) and Escherichia coli resistance (Berghof et al., 2019).

These antibodies are produced by a subset of B cells known as B-1 cells as part of the innate immune system, without any antigenic stimulation (Avrameas, 1991). They provide a first line of defense against pathogens before specific antibodies are produced as part of the adaptive immune response. Natural antibodies have a polyreactive nature and low affinity and target selfantigens and other molecules such as keyhole limpet hemocyanin (KLH) and pathogen-associated molecular patterns (PAMP; Baumgarth et al., 2005). Relevant microbial PAMP include lipoteichoic acid (LTA), LPS, and peptidoglycan (PGN).

Antibodies (also called immunoglobulins) in general are classified into isotypes such as IgM, IgG, IgA, and others based on their heavy chain structure. In early stages of an infection, IgM is the first isotype produced, allowing a quick response to a variety of PAMP or other antigens (Schroeder and Cavacini, 2010). Upon antigenic stimulation, B cells may switch isotype and convert into plasma cells that produce more specific IgG antibodies (Liljavirta et al., 2014). An important part of this immune response rests on $\mathrm{NAb}$, making them an interesting target to potentially select for disease resistance.

The NAb titers in milk are repeatable (Ploegaert et al., 2011) and heritable (Wijga et al., 2013), but little is 
known about the underlying genes. Based on genotypic information of thousands of SNP from individuals in a population, it is possible to perform a genome-wide association study (GWAS). This analysis may detect genomic regions involved in traits, leading to the identification of favorable variants and, potentially, candidate genes (e.g., Hayes and Goddard, 2010). Information from a GWAS might be used in selective breeding and might increase our understanding of the immunological background of NAb. The aim of this study was to identify genomic regions associated with different $\mathrm{NAb}$ traits in milk and potentially describe candidate genes.

\section{MATERIALS AND METHODS}

A brief overview of the methods is provided. Additional details about the milk samples and NAb analysis can be found in Wijga et al. (2013).

\section{Cows and Phenotypes}

Milk samples and phenotypes were collected as part of the Dutch Milk Genomics Initiative (for details, see Stoop et al., 2008). The NAb levels were measured as titers. Phenotypes included in the present study were (1) total NAb titers binding the antigens KLH, LPS, LTA, or PGN without isotype distinction and (2) NAb isotypes $\operatorname{IgA}, \operatorname{Ig} G_{1}$, and IgM titers binding $\mathrm{KLH}$, LPS, LTA, and PGN, for a total of 16 traits.

Titers were measured in morning milk samples using an indirect ELISA (Ploegaert et al., 2010) and were available for 1,695 genotyped cows that were at least $87.5 \%$ Holstein-Friesian and housed in 380 commercial dairy herds across the Netherlands. The average number of days in lactation when milk samples were taken was $166 \mathrm{~d}$, with a range of 66 to $263 \mathrm{~d}$. The pedigree used contained 12,998 animals (4 generations) and was made available by the Dutch cattle cooperative CRV (Arnhem, the Netherlands).

\section{Genotypes}

The DNA was extracted from blood samples of the cows. They were sampled in agreement with the directive for animal use and care as approved by the ethical committee on animal experiments of Wageningen University (protocol no. 200523.b). Cows were genotyped for 50,905 SNP with a custom Infinium assay (Illumina, San Diego, CA) designed by CRV. Imputed 777K SNP data from the aforementioned 50K SNP array genotypes were available for 1,736 animals from the Milk Genomics project. Further information about the genotyping and imputation of the samples can found in Duchemin et al. (2014). The SNP positions were mapped using
bosTau8 assembly of the bovine genome (UMD 3.1.1; Zimin et al., 2009).

\section{GWAS}

The GWAS were performed using the following animal model:

$$
\begin{aligned}
& y_{i j k l m n o}=\mu+\beta_{1} D I M_{i j k l m n o}+\beta_{2} e^{-0.05 \times D I M_{i j k l m n o}} \\
& +\beta_{3} \text { ca }_{i j k l m n o}+\beta_{4} \text { ca }_{i j k l m n o}^{2}+\text { season }_{k}+\text { scode }_{l} \\
& +S N P_{m}+\text { herd }_{n}+\text { animal }_{o}+e_{i j k l m n o}
\end{aligned}
$$

where $\beta_{1,2}$ are the regression coefficients for $D I M_{i j k l m n o}$; $\beta_{3,4}$ are the regression coefficients for $c a_{i j k l m n o} ; y$ is the observation of the NAb titer; $\mu$ is the overall mean of the trait; DIM $M_{i j k l m n o}$ is a covariate describing the effect of days in lactation, modeled with a Wilmink curve (Wilmink, 1987); $c a_{i j k l m n o}$ is a covariate accounting for the effect of age at first calving; season ${ }_{k}$ is the fixed effect with 3 classes of calving season (June-August 2004, September-November 2004, and December 2004-February 2005); scode $_{l}$ is the fixed effect of sire type in 3 classes (proven bull, young bull, or other proven bull); $S N P_{m}$ is the fixed effect of SNP genotype; herd $d_{n}$ is the random herd effect assumed to be distributed as $N\left(0, \mathbf{I} \sigma_{\text {herd }}^{2}\right)$, where $\mathbf{I}$ is the identity matrix and $\sigma_{\text {herd }}^{2}$ is the herd variance; animal $_{o}$ is the random additive genetic effect assumed to be distributed as $N\left(0, \mathbf{A} \sigma_{a}^{2}\right)$, where $\mathbf{A}$ is the additive genetic relationships matrix from the pedigree and $\sigma_{a}^{2}$ is the additive genetic variance; and $e_{i j k l m n o}$ is the random residual effect assumed to be distributed as $N\left(0, \mathbf{I} \sigma_{e}^{2}\right)$, where $\mathbf{I}$ is the identity matrix and $\sigma_{e}^{2}$ is the residual variance.

The additive genetic variance and the herd variance were fixed at the values calculated from analyses based on Equation 1 without the inclusion of SNP effects. The additive genetic variance, herd variance, and other genetic parameters were previously reported by Wijga et al. (2013). All the analyses were performed using ASReml 4.1 (Gilmour et al., 2015).

For quality control, monomorphic SNP were removed and SNP with genotype classes of 1 to 10 cows were excluded from the GWAS, for a minor allele frequency of 0.08. The SNP with a strong deviation from HardyWeinberg equilibrium $\left(\chi^{2} \geq 600\right)$ were also excluded. Regarding significant SNP, the sensitivity of association was evaluated if they had a genotype class with fewer than 50 cows. In those cases, that genotype class was removed and the SNP were retested to confirm the significance of the association. Furthermore, significant SNP were inspected for extreme phenotypes. Pheno- 
types were regarded as extreme when their residuals (Equation 1) were larger than $3.5 \mathrm{SD}$. If extreme phenotypes were found, the SNP was retested without these extreme phenotypes. Genomic inflation factor was accounted for using genomic-control correction dividing the $F$-test statistics by the genomic inflation factor and recalculating the $P$-values.

To control the number of false positives due to multiple testing, we applied a false discovery rate (FDR) threshold using the R package "qvalue" (Storey et al., 2015). The SNP associations were considered suggestive if $0.05<\mathrm{FDR}<0.20$ and significant if $\mathrm{FDR}<0.05$. Suggestive and significant associations were grouped into genomic regions, and SNP were considered in the same region based on 2 criteria: (1) they were less than $200 \mathrm{~kb}$ apart, where the linkage disequilibrium correlation coefficient $\mathrm{r}^{2}$ value is assumed to decrease to approximately 0.15 (de Roos et al., 2008; Khatkar et al., 2008), or (2) fitting 2 of them simultaneously in Equation 1 reduced their significance, suggesting some degree of linkage disequilibrium.

\section{Candidate Genes}

For the regions associated with the NAb traits, we searched for genes within those regions in the NCBI (NCBI Resource Coordinators, 2018) and Ensembl (Zerbino et al., 2018) databases. We used the bovine UMD 3.1.1 assembly for the GWAS SNP mapping; this includes the positions and ranges referenced in the tables and results. However, for the candidate gene search, we also used the ARS-UCD1.2 assembly (Rosen et al., 2018), which provides more recent information about the bovine genome. To prevent confusion, it is clearly stated in the Results section whenever this build is used instead of or in addition to UMD 3.1.1.

After gathering the genes in each region, we analyzed them through WebGestalt (Wang et al., 2017), a functional enrichment analysis web tool, to determine which biological pathways they were related to. The search within WebGestalt included 4 databases: KEGG (Kanehisa et al., 2017), Panther (Mi et al., 2017), Reactome (Fabregat et al., 2018), and WikiPathways (Slenter et al., 2018).

\section{RESULTS}

In this study, we analyzed 16 traits, including total NAb titers binding KLH, LPS, LTA, or PGN without isotype distinction and $\mathrm{NAb}$ isotypes $\operatorname{IgA}, \operatorname{IgG}_{1}$, and IgM titers binding KLH, LPS, LTA, and PGN. Means, standard deviations, heritabilities, and herd effects are shown in Table 1. In general, isotypes IgA and IgM
Table 1. Mean, SD, heritability $\left(h^{2}\right)$, and herd effect ${ }^{1}$ (SE in parentheses) for total natural antibody (NAb) titers (T) and $\mathrm{NAb}$ isotype $\operatorname{IgA}, \operatorname{IgG}_{1}$, and $\operatorname{IgM}$ titers binding keyhole limpet hemocyanin (KLH), LPS, lipoteichoic acid (LTA), or peptidoglycan (PGN)

\begin{tabular}{lcccc}
\hline Trait & Mean & SD & $h^{2}$ & Herd effect \\
\hline KLH-T & 4.88 & 0.76 & $0.34(0.08)$ & $0.16(0.03)$ \\
KLH-IgA & 0.99 & 0.98 & $0.48(0.10)$ & $0.16(0.03)$ \\
KLH-IgG & 2.96 & 1.49 & $0.32(0.08)$ & $0.25(0.04)$ \\
KLH-IgM & 2.31 & 0.99 & $0.41(0.09)$ & $0.08(0.02)$ \\
LPS-T & 4.20 & 0.97 & $0.13(0.06)$ & $0.13(0.03)$ \\
LPS-IgA & 1.95 & 1.13 & $0.48(0.10)$ & $0.08(0.02)$ \\
LPS-IgG & 3.06 & 1.43 & $0.20(0.07)$ & $0.18(0.03)$ \\
LPS-IgM & 2.62 & 1.03 & $0.39(0.09)$ & $0.09(0.02)$ \\
LTA-T & 4.43 & 0.89 & $0.28(0.08)$ & $0.14(0.03)$ \\
LTA-IgA & 3.86 & 1.16 & $0.37(0.09)$ & $0.31(0.04)$ \\
LTA-IgG & 4.39 & 1.38 & $0.06(0.04)$ & $0.37(0.05)$ \\
LTA-IgM & 5.26 & 0.89 & $0.39(0.09)$ & $0.13(0.03)$ \\
PGN-T & 6.67 & 1.04 & $0.10(0.04)$ & $0.36(0.05)$ \\
PGN-IgA & 0.05 & 0.96 & $0.26(0.08)$ & $0.16(0.03)$ \\
PGN-IgG & 5.45 & 1.40 & $0.12(0.05)$ & $0.26(0.04)$ \\
PGN-IgM & 2.18 & 0.90 & $0.35(0.09)$ & $0.10(0.03)$ \\
\hline
\end{tabular}

${ }^{1}$ Heritabilities and herd effects were taken from Wijga et al. (2013).

tended to have higher heritability estimates than $\operatorname{IgG}_{1}$ isotypes. Our GWAS was performed based on 1,630 animals, which had information for NAb phenotypes and $777 \mathrm{~K}$ imputed genotypes. Out of 664,119 SNP, a total of 567,461 were used for the analysis after quality control. The genomic inflation factor ranged between 1.09 and 1.31, and genomic-control correction was applied on all traits for consistency. After this correction, all new inflation factor values were less than 1 (Supplemental Figure S1, https://doi.org/10.3168/jds .2019-16627).

We found 5 genomic regions to be significantly associated with NAb titers in milk on 4 different chromosomes. Additionally, 6 suggestive regions were found on 5 other chromosomes (Table 2). Traits with significant or suggestive associations were LPS-IgG ${ }_{1}$, PGN-IgG LTA-IgG ${ }_{1}$, LTA-IgM, and PGN-IgM (Figure 1). No genomic regions were found significantly or suggestively associated with any of the KLH traits and either IgA or total NAb for the other antigens. Lead SNP for genomic regions with significant or suggestive associations are presented in Table 3. None of the lead SNP deviated from Hardy-Weinberg equilibrium $\left(\chi^{2}<5.3\right)$.

\section{$\lg G_{1}$ Phenotypes}

Two genomic regions were found to be significantly associated with $\operatorname{IgG}_{1}$ antibodies. The strongest one was on chromosome 21 (BTA21) for PGN-IgG 1 , spanning from approximately 65 to $71 \mathrm{Mbp}$. It includes 36 significant and 55 suggestive SNP, with the lead SNP, BovineHD2100020570 (rs137230097), located at $70,399,861 \mathrm{bp}$. The other region was on BTA3 
Table 2. Genomic regions with suggestive or significant associations with natural antibody titers

\begin{tabular}{|c|c|c|c|c|}
\hline \multirow[b]{2}{*}{ Trait $^{1}$} & \multirow[b]{2}{*}{ Chromosome } & \multirow[b]{2}{*}{ Position range (bp) } & \multicolumn{2}{|c|}{ No. of SNP } \\
\hline & & & Significant & Suggestive \\
\hline $\begin{array}{l}\text { PGN-IgG } \\
\text { LPS-IgG }_{1}\end{array}$ & 3 & $6,266,886-8,339,166$ & $\begin{array}{l}3 \\
6\end{array}$ & $\begin{array}{r}12 \\
7\end{array}$ \\
\hline LTA-IgM & 17 & $72,522,707-73,625,915$ & 2 & 0 \\
\hline $\begin{array}{l}\text { LTA-IgM } \\
\text { PGN-IgM }\end{array}$ & 18 & $\begin{array}{l}46,339,220-50,839,220 \\
46,339,220-55,991,489\end{array}$ & $\begin{array}{l}0 \\
3\end{array}$ & $\begin{array}{l}1 \\
0\end{array}$ \\
\hline $\begin{array}{l}\text { PGN-IgG } \\
\text { LTA-IgM }\end{array}$ & 21 & $\begin{array}{l}65,998,120-71,599,094 \\
69,464,920-71,599,094\end{array}$ & $\begin{array}{r}36 \\
4\end{array}$ & $\begin{array}{r}55 \\
1\end{array}$ \\
\hline LPS-IgG 1 & 2 & $132,997,243-133,569,811$ & 0 & 17 \\
\hline LPS-IgG 1 & 9 & $\begin{array}{l}34,253,477-34,653,477 \\
65,759,809-67,772,036\end{array}$ & $\begin{array}{l}0 \\
0\end{array}$ & $\begin{array}{l}1 \\
2\end{array}$ \\
\hline PGN-IgG $_{1}$ & 10 & $31,297,978-31,704,729$ & 0 & 2 \\
\hline $\mathrm{PGN} \mathrm{IgG}_{1}$ & 24 & $17,964,011-19,750,629$ & 0 & 1 \\
\hline LTA-IgG 1 & 29 & $10,932,414-15,317,753$ & 0 & 14 \\
\hline
\end{tabular}

${ }^{1} \mathrm{PGN}=$ peptidoglycan; LTA $=$ lipoteichoic acid.

for PGN-IgG ${ }_{1}$ and $\mathrm{LPS}-\operatorname{IgG}_{1}$, around 6 to $8 \mathrm{Mbp}$. It consisted of 3 significant and 12 suggestive SNP for PGN-IgG $\mathrm{I}_{1}$ and 6 significant and 7 suggestive SNP for LPS-IgG ${ }_{1}$. They did not share the lead SNP, with ARSBFGL-NGS-25819 (rs110900415) at 7,416,886 bp for PGN-IgG $_{1}$ and BovineHD0300002588 (rs109075424) at $7,931,301 \mathrm{bp}$ for LPS-IgG .

Six other regions were suggestively associated with $\mathrm{IgG}_{1}$ traits. However, no traits had any overlapping region. For $\mathrm{PGN}_{-} \operatorname{IgG}_{1}, 2$ regions were found, one in BTA10 and the other in BTA24, with the lead SNP around 31.5 and $18.1 \mathrm{Mbp}$, respectively. For LPS- $\operatorname{IgG}_{1}$ there were 3 regions in 2 chromosomes, with BTA2 having the lead SNP at $133.3 \mathrm{Mbp}$ and BTA9 containing 2 regions with the lead SNP at 34.4 and $67.5 \mathrm{Mbp}$. For LTA-IgG ${ }_{1}$ there was only 1 region at BTA29, peaking at approximately $15.1 \mathrm{Mbp}$.

\section{IgM Phenotypes}

Three significantly associated regions were found for IgM traits. The strongest association was found on BTA21 around the same region where an association for $\mathrm{IgG}_{1}$ was detected: from 69 to $71 \mathrm{Mbp}$. It includes 4 significant and 1 suggestive SNP, with BovineHD2100020886 (rs135338912) located at 71,482,201 bp as the lead SNP. Also, LTA-IgM was significantly associated with another region on BTA17, from approximately 72 to $73 \mathrm{Mbp}$. Only 2 significant SNP were found, with the lead SNP BovineHD1700021382 (rs133519711) at 73,125,915 bp.
The third region was on BTA18, associated with PGNIgM comprising 3 SNP, with BovineHD1800016327 (rs41892312) and BovineHD1800016328 (rs41892314) as the lead SNP at 55,788,547 and 55,791,489 bp, respectively. The other SNP significantly associated with PGN-IgM, BovineHD1800014677 (rs134833064) at $49,839,220$ bp, had a suggestive association with LTAIgM as well.

\section{Candidate Genes}

Candidate genes within genomic regions significantly associated with NAb titers and pathways are presented in Table 4. Genes associated with immunity and especially B cell function were selected, prioritizing genes close to the lead SNP in said region. Some regions included genes with a known role in humoral immune response but were not in any of the pathways databases; we included these genes as well.

Bos taurus autosome 21 was the chromosome with the strongest GWAS signal. Two traits from different isotypes ( $\mathrm{PGN}-\mathrm{IgG}_{1}$ and LTA-IgM) had significant associations around the same region $(65-71 \mathrm{Mbp})$ but different lead SNP (Table 3). To test whether this was a single QTL with a pleiotropic effect on both traits, we ran the GWAS using Equation 1 but with $2 \mathrm{SNP}$ that is, the lead SNP on BTA21, either for PGN-IgG (rs137230097) or LTA-IgM (rs135338912), and any of the other SNP on BTA21. When LTA-IgM was cor-

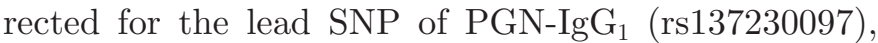
the GWAS signal did not disappear. A similar pattern 
was observed for PGN-IgG 1 when it was corrected for the lead SNP of LTA-IgM. This suggests that separate loci in this region influence PGN-IgG ${ }_{1}$ and LTA-IgM. Further evidence to support this idea comes from the ARS-UCD1.2 assembly, which relocates an $\sim 1-\mathrm{Mbp}$ fragment of BTA21 located at the $\sim 71.5-\mathrm{Mbp}$ region (which includes all 5 SNP associated with LTA-IgM) to BTA20 around the $\sim 71.9-\mathrm{Mbp}$ region along with the genes around the significant SNP, whereas the SNP for PGN-IgM remain in BTA21. For LTA-IgM, the lead SNP (rs135338912) was also the marker with the highest $-\log _{10} P$-values for KLH-IgM and LPS-IgM (5.1 and 3.9 , respectively), but these 2 traits did not reach the significance threshold. Genotype effects for rs135338912
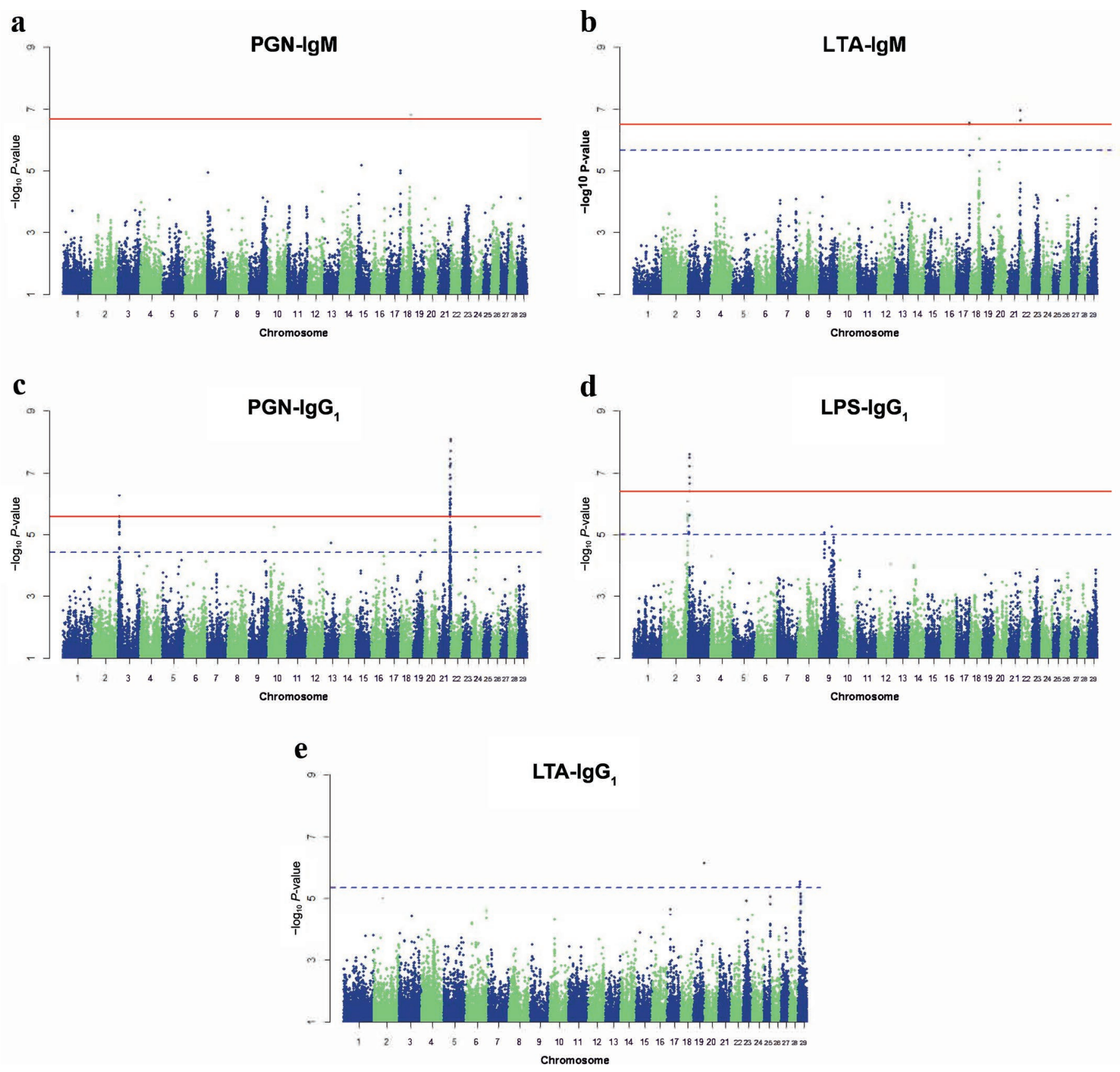

Figure 1. Genome-wide association study (GWAS) plots on natural antibody (NAb) titers from milk (a) peptidoglycan (PGN)-IgM, (b) lipoteichoic acid (LTA)-IgM, (c) PGN-IgG the NAb trait. The false discovery rate (FDR) threshold was set at 0.05 for significant SNP (solid line) and at 0.20 for suggestive SNP (dotted line). For LTA-IgG ${ }_{1}$, no $-\log _{10} P$-value reached FDR $<0.05$. In the case of PGN-IgM, no SNP was $0.05<$ FDR $<0.20$, so no blue line is shown. 
on these 3 traits were additive, and genotypic effects on the 3 traits were in the same direction. There are 4 immunoglobulin structural genes on BTA21 from 71.4 to $71.6 \mathrm{Mbp}$ : IgE heavy chain constant region (IGHE), Ig heavy chain $\mathrm{V}$ region PJ14 (IGHV1S20), Ig heavy chain Mem5-like (IGHV1S18), and IgM (IGHV and IGHV1S15 to 17 ). According to the KEGG database (Kanehisa et al., 2017), aside from being structural genes for IgM, the last 3 are also part of several immunity-related pathways such as B cell receptor signaling, nuclear factor- $\kappa \mathrm{B}(\mathbf{N F}-\kappa \mathbf{B})$ signaling, and PI3K-Akt signaling; therefore, we propose them as candidate

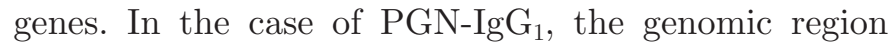
is approximately $5.6 \mathrm{Mbp}$ long, comprising about 70 reported genes, but only a few of these seem to be related to antibodies. From the KEGG database, we find the genes TNF receptor-associated factor 3 (TRAF3) and AKT serine/threonine kinase 1 (AKT1) both to be involved in tumor necrosis factor signaling and Toll-like receptor signaling. By itself, AKT1 is involved in $\mathrm{B}$ cell receptor signaling, PI3K-Akt signaling, and Fc gamma receptor-mediated phagocytosis, among other things. WikiPathways (Slenter et al., 2018) also links this gene with IL-1 to 7, 11, and 17 signaling pathways. Another gene in this region is protein phosphatase 2 regulatory subunit $\mathrm{B}^{\prime}$ gamma (PPP2R5C), reported to be part of PI3K-Akt signaling (KEGG) and a negative regulator of NF- $\kappa \mathrm{B}$ in $\mathrm{T}$ cell receptor signaling (Breuer et al., 2014).

The second chromosome with highly significant SNP was BTA3. On this chromosome, $2 \mathrm{IgG}_{1}$ traits (PGN$\mathrm{IgG}_{1}$ and $\left.\mathrm{LPS}-\mathrm{IgG}_{1}\right)$ showed significant associations. The top 5 SNP for LPS-IgG 1 (rs109075424, rs109851797, rs110532702, rs43709885, and rs110858854) were also the highest for KLH-IgG ${ }_{1}$; however, significance for this trait was below the FDR $<0.20$ threshold. Genotypic effects for these 5 markers and rs110900415 (the PGN$\mathrm{IgG}_{1}$ lead SNP) were additive, and genotypic effects were in the same direction for KLH-IG1, PGN-IgG , $_{1}$ and LPS-IgG $\mathrm{G}_{1}$. Three of these SNP were within intronic regions of the $\mathrm{Fc}$ fragment of the $\mathrm{IgG}$ receptor IIb $(F C G R 2 B)$ gene and 1 in the $3^{\prime}$ untranslated region. Five suggestive SNP for LPS-IgG ${ }_{1}$ and 3 for PGN-IgG fell within the Fc receptor-like A $(F C R L A)$ gene, spanning introns and near-gene regions. From the KEGG database, FCGR2B is part of $\mathrm{B}$ cell receptor signaling and the phagosome and $\mathrm{Fc}$ gamma receptor-mediated phagocytosis pathways and, according to Reactome,

Table 3. Lead SNP for genomic regions with significant or suggestive association with natural antibody titers

\begin{tabular}{|c|c|c|c|c|c|c|c|}
\hline Chromosome & $\begin{array}{l}\text { Position } \\
\text { (bp) }\end{array}$ & Trait $^{1}$ & SNP & $\mathrm{MAF}^{2}$ & $\begin{array}{l}\text { Major/minor } \\
\text { allele }\end{array}$ & $\begin{array}{l}\text { Genotype } \\
\text { effect }^{3} \text { (SE) }\end{array}$ & $\begin{array}{l}-\log _{10} \\
P \text {-value }\end{array}$ \\
\hline 21 & $70,399,861$ & PGN-IgG ${ }_{1}$ & rs137230097 & 0.29 & $\mathrm{G} / \mathrm{A}$ & $\begin{array}{l}\text { GG: }-0.35(0.07) \\
\text { AA: } 0.35(0.12)\end{array}$ & 8.1 \\
\hline 3 & $7,931,301$ & LPS-IgG ${ }_{1}$ & rs109075424 & 0.35 & $\mathrm{~A} / \mathrm{C}$ & $\begin{array}{l}\text { AA: }-0.40(0.07) \\
\text { CC: } 0.24(0.11)\end{array}$ & 7.6 \\
\hline \multirow[t]{2}{*}{18} & $\begin{array}{l}55,788,547 \\
55,791,489\end{array}$ & PGN-IgM & $\begin{array}{l}\text { rs41892312 } \\
\text { rs41892314 }\end{array}$ & 0.36 & $\mathrm{~T} / \mathrm{C}$ & $\begin{array}{l}\text { TT: }-0.29(0.05) \\
\text { CC: } 0.11(0.07)\end{array}$ & 6.8 \\
\hline & $49,839,220$ & LTA-IgM & rs134833064 & 0.38 & $\mathrm{G} / \mathrm{A}$ & $\begin{array}{l}\text { GG: }-0.28(0.05) \\
\text { AA: } 0.08(0.06)\end{array}$ & $6.0^{4}$ \\
\hline 17 & $73,125,915$ & LTA-IgM & rs133519711 & 0.10 & $\mathrm{~A} / \mathrm{G}$ & $\begin{array}{l}\text { AA: } 0.35(0.06) \\
\text { GG: } 0.04(0.24)\end{array}$ & 6.5 \\
\hline 2 & $133,363,107$ & LPS-IgG & rs110155136 & 0.36 & $\mathrm{G} / \mathrm{A}$ & $\begin{array}{l}\text { GG: }-0.38(0.08) \\
\text { AA: } 0.17(0.11)\end{array}$ & $6.1^{4}$ \\
\hline 24 & $18,164,011$ & $\mathrm{PGN}^{-\mathrm{IgG}_{1}}$ & rs134716898 & 0.43 & $\mathrm{~T} / \mathrm{C}$ & $\begin{array}{l}\text { TT: } 0.06(0.08) \\
\text { CC: } 0.47(0.09)\end{array}$ & $5.2^{4}$ \\
\hline \multirow[t]{2}{*}{9} & $34,453,477$ & LPS-IgG $_{1}$ & rs43597502 & 0.17 & $\mathrm{~T} / \mathrm{C}$ & $\begin{array}{l}\text { TT: }-0.41(0.08) \\
\text { CC: } 0.09(0.20)\end{array}$ & $5.1^{4}$ \\
\hline & $67,559,809$ & LPS-IgG $_{1}$ & rs133427557 & 0.34 & $\mathrm{C} / \mathrm{T}$ & $\begin{array}{l}\text { CC: }-0.27(0.07) \\
\text { TT: } 0.32(0.11)\end{array}$ & $5.3^{4}$ \\
\hline
\end{tabular}

${ }^{1} \mathrm{PGN}=$ peptidoglycan; LTA $=$ lipoteichoic acid.

${ }^{2}$ Minor allele frequency.

${ }^{3}$ The genotype effects are compared with the heterozygous genotype class.

${ }^{4}$ Suggestive association $(0.05<$ false discovery rate $<0.20)$. 
CORDERO-SOLORZANO ETAL.

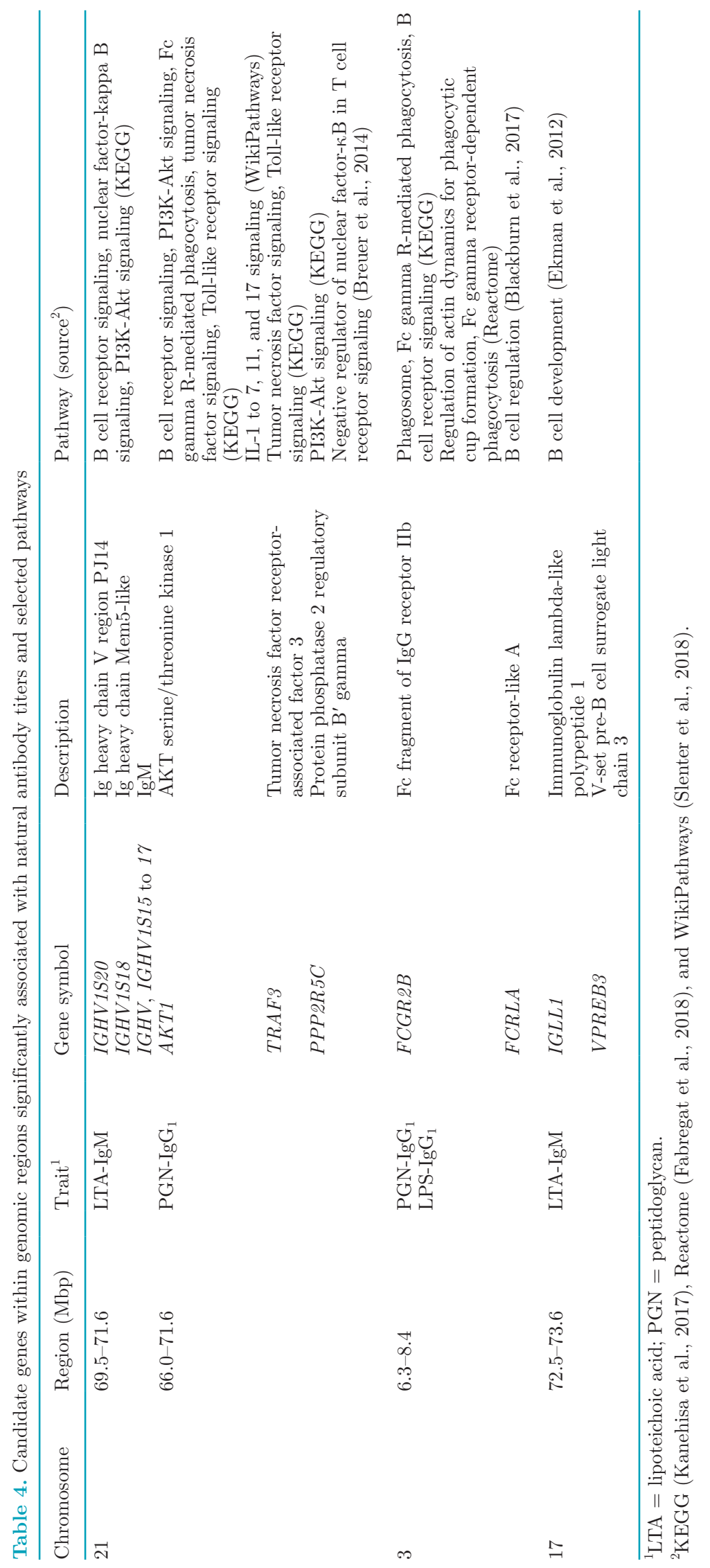


regulation of actin dynamics for phagocytic cup formation. In the case of FCRLA, this gene is not reported in any of the databases, but it might be involved in $\mathrm{B}$ cell regulation (Blackburn et al., 2017).

For BTA17, only LTA-IgM had significant associations, but the top 3 markers with the highest $-\log _{10}$ $P$-values for this trait (rs133519711, rs135566843, and rs41854290) were also the highest for PGN-IgM and KLH-IgM (values ranged from 4.3 to 5.0), although these traits did not reach the FDR $<0.20$ threshold. Notably, the genotype effects for these SNP on LTAIgM, PGN-IgM, and KLH-IgM were all in the same direction and showed complete dominance; the effect of heterozygote did not differ significantly from one of the homozygotes. None of the genes in this genomic region were reported in the databases as part of any humoral response-related pathways. However, immunoglobulin lambda-like polypeptide 1 (IGLL1) and V-set pre-B cell surrogate light chain 3 (VPREB3) are known for playing an important role in B cell development (Ekman et al., 2012). Also, according to the ARS-UCD1.2 assembly, the 3 aforementioned SNP fall within IGLL1.

The genomic region in BTA18 for PGN-IgM is $\sim 10$ Mbp long because the 2 lead SNP are $\sim 6$ Mbp away from the rest of the significant and suggestive SNP. To check whether this region comprised 2 separate QTL, we performed additional analyses using Equation 1 but with 2 SNP: one of the lead SNP located at $55.8 \mathrm{Mbp}$ and correcting for another significant SNP (rs134833064) located at $49.8 \mathrm{Mbp}$. When they were fit together in the model, their significance decreased, suggesting that these markers are in linkage disequilibrium. There are 486 annotated genes in this region. After analyzing the region through the pathways databases, these genes were the most recurring among humoral response-related pathways: NF- $\mathrm{BB}$ inhibitor $\beta$ (NFK$B I B)$, AKT serine/threonine kinase 2 (AKT2), CD79a molecule $\left(C D^{79} A\right)$, sphingosine kinase 2 (SPHK2), and calmodulin 3 (CALM3); SPHK2 was the closest to the lead SNP ( $65 \mathrm{kbp})$, and AKT2 was closer to the other significance peak around $49.8 \mathrm{Mbp}(\sim 62 \mathrm{kbp})$.

For chromosomes with only suggestive associations, BTA2 comprised a region with 15 annotated genes, 10 of which were $\mathrm{A}_{2}$ phospholipases. For BTA9, close to the only suggestive $\mathrm{SNP}$ around $34.5 \mathrm{Mbp}$, there is 1 gene involved in the NOD-like receptor signaling pathway (KEGG), and close to the other QTL at 67.6 Mbp, the 2 suggestive SNP (rs133427557 and rs133434357) fall within intronic regions of protein tyrosine phosphatase receptor type $\mathrm{K}(P T P R K)$, a gene involved in T-helper cell development (Erdenebayar et al., 2009) and epidermis growth factor receptor downregulation (Reactome). In the case of BTA10, BTA24, and BTA29, no genes had an apparent role in humoral immunity.

\section{DISCUSSION}

In the present study, we identified QTL influencing NAb titers using imputed 777K SNP genotypes. We found 5 significant regions on 4 chromosomes and 6 suggestive regions on 5 other chromosomes associated with $\operatorname{IgG}_{1}$ and IgM NAb titers in milk.

Four antigens were used to measure NAb: KLH, LPS, LTA, and PGN. The last 3 are microbial PAMP found on bacteria such as E. coli and Staphylococcus aureus (Baumgarth et al., 2005), which are ubiquitous in most environments. Cows in our study were not deliberately exposed to or inoculated with any of these 4 antigens, so we regard the titers of antibodies against them as NAb reflecting the animals' innate humoral response. Given the universal presence of LPS, LTA, and PGN, it is reasonable to assume that the measurements could partly represent antibodies produced as part of the adaptive immune response. On the other hand, KLH is considered a true measure of NAb because cows are not normally exposed to this antigen (van Knegsel et al., 2007).

No significant associations were found for any of the $\mathrm{KLH} \mathrm{NAb}$ isotypes, but there were some cases in which the lead SNP in a chromosome for a significant trait was also the lead SNP for KLH. This was the case for KLH-IgM with LTA-IgM on chromosomes 17 and 21 as well as KLH-IgG $\mathrm{I}_{1}$ with $\mathrm{LPS} \operatorname{IgG}_{1}$ on chromosome 3. A possible explanation might be that these genomic regions comprise genes related to innate immune response or shared between innate and adaptive immune response.

There were also no associations found for any $\operatorname{Ig} \mathrm{A}$ or total NAb traits. For the latter, this could be due to a dilution effect; the trait includes all isotypes at the same time, which are mostly regulated by different genetic mechanisms, creating additional noise in the GWAS signal. For IgA, the results are quite intriguing because genetic correlations with IgM NAb are very strong and larger than 0.8 (Wijga et al., 2013). It is possible that the SNP genotypes do not cover genomic regions involved in shared regulatory mechanisms between both isotypes. Further analyses with IgA NAb are required to better understand this.

A previous GWAS on bovine NAb (de Klerk et al., 2018) identified genomic regions of interest. They analyzed NAb on Canadian Holstein cow serum using a $50 \mathrm{~K}$ SNP array and found a region on BTA21 from 55.5 to $70.6 \mathrm{Mbp}$ that was significantly associated with KLH-IgG, overlapping with our region from 66.0 to

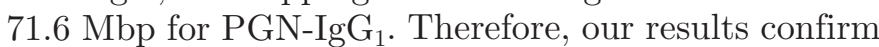
findings by de Klerk et al. (2018), which is remarkable because there are important trait differences between both studies: our samples were taken from milk, 
whereas theirs were from serum; we analyzed $\operatorname{IgG}_{1}$ (an isotype subclass) and they analyzed IgG (which includes all isotype subclasses); and the antigens used were different. It has been shown that there is a high genetic correlation between $\mathrm{NAb}$ of the same isotype in serum and milk: $0.79( \pm 0.09 ; \pm \mathrm{SE})$ for $\operatorname{IgM}$ and 0.81 $( \pm 0.18)$ for $\operatorname{IgG}$ (de Klerk et al., 2015). Also, $\operatorname{IgG}_{1}$ is the predominant subclass in both serum and milk $(\sim 56$ and 74\%, respectively; Marnila and Korhonen, 2011). This implies that even if KLH-IgG from serum and $\mathrm{PGN} \mathrm{IgG}_{1}$ in milk are different traits, it is reasonable to assume that they share genetic regulatory mechanisms. As far as we know, the other genomic regions we found have not been reported in other NAb or specific antibody studies in cattle.

\section{Role of Candidate Genes}

IgM. Development of $\mathrm{B}$ cells involves different stages and checkpoints before moving on to the next phase. The pro-B stage requires rearrangement and expression of immunoglobulin heavy-chain (IgH) precursors [including IGHV gene family (BTA21); Spanopoulou et al., 1994]. After that, at the pre-B cell stage, the production of surrogate light chain [encoded by IGLL1 (BTA17) and VPREB1] is required (Mundt et al., 2001). Then, surrogate light chain assembles with $\mathrm{IgH}$ to form the pre-B cell receptor, temporarily substituting the actual immunoglobulin light chain. When this receptor assembles, the cells proliferate and later rearrange and produce immunoglobulin light chain to form a B cell receptor (Almqvist and Mårtensson, 2012).

How well $\operatorname{IgH}$ associates with surrogate light chain and the reactivity of $\mathrm{B}$ cell receptors with self-antigens affects cell survival, ultimately having an important effect on B cell repertoire (Melchers et al., 2000; Herzog and Jumaa, 2012). Our proposed candidate genes for IgM NAb (BTA17 and 21) may have an independent influence during early stages of development.

$I g G_{1}$. The Fc receptors are molecules on the surface of cells that recognize and attach to the Fc region of immunoglobulins, playing a role in the regulation of innate and adaptive immunity. These receptors are expressed in several immune cells such as macrophages, neutrophils, and others (Moldt and Hessell, 2014). Interestingly, only $1 \mathrm{Fc}$ receptor is known to be expressed on B cells: Fc $\gamma$ RIIb, which binds to IgG antibodies and is encoded by the gene FCGR2B (BTA3). This is a negative regulator that prevents overstimulation of $\mathrm{B}$ cells and activation of low-affinity, self-reactive B cell receptors (Walsh and Bolland, 2014). A study on human immunoglobulin levels linked FCGR2B with total IgG concentration. Mutation analyses revealed a positive effect through loss of function (Jonsson et al., 2017) because Fc $\gamma$ RIIb receptor suppresses IgG production (Hogarth and Pietersz, 2012). This is consistent with our results for PGN-IgG ${ }_{1}$ and LPS-IgG I $_{1}$ on BTA3, where genotype effects show an additive pattern (Table 3 ); however, the alternative allele had a positive effect.

In this same region, we find another candidate gene that belongs to the family of Fc receptor-like molecules (FCRLA3). This receptor is a soluble protein located in the endoplasmic reticulum that can bind to multiple Ig isotypes (Wilson et al., 2010; Reshetnikova et al., 2012). Although its exact role is still unknown, it has been speculated that it may enhance stimulation from T-helper cells, facilitating class switching (Blackburn et al., 2017).

On chromosome 21, TRAF3 is an adapter protein that is expressed in several immune cells (including B cells) and plays many roles in immune function regulation. Jonsson et al. (2017) found an association with this gene and class switching for IgA and IgG, confirming a previous study that showed that TRAF3 plays a key role in CD40-mediated class switching (Jabara et al., 2009). This gene has also been shown to negatively regulate homeostatic survival of B cells (Moore et al., 2012) and to play an essential role in T cell-dependent $\mathrm{IgG}_{1}$ production (Xie et al., 2011), among other things. The TRAF3 gene is in the genomic region that overlaps with the QTL found by de Klerk et al. (2018), and it is one of their proposed candidate genes.

As for PPP2R5C, it expresses the regulatory subunit B56 $\gamma$ of protein phosphatase $2 \mathrm{~A}$. This enzyme has been shown to suppress the activation of NF- $\kappa \mathrm{B}$ in $\mathrm{T}$ cells (Breuer et al., 2014). Also, PPP2R5C is a modulator of liver metabolism, constituting an important factor in energy metabolism and maintenance of a metabolically healthy state (Cheng et al., 2015). de Klerk et al. (2015) found that NAb levels are indicators of potential problems after calving related to negative energy balance. This gene suggests a link between NAb and health status through liver metabolism.

Another candidate gene in this region, AKT1, is part of the PI3K-AKT pathway, which plays a central and diverse role in many cell types, involving cell growth, proliferation, and survival. The immunological functions of AKT1 appear to be rather broad and still not fully understood. Some of the known functions include T cell development (together with AKT2; Juntilla et al., 2007) and FOXO1 signaling, which involves maturation and survival of peripheral B cells and class switching (Calamito et al., 2010; Chen et al., 2010).

It seems plausible that variation in these candidate genes associated with $\operatorname{IgG}_{1}$ titers might have an effect on class switching via different but related mechanisms involving T-helper cells. This could imply that the 
observed effects on $\operatorname{IgG}_{1}$ are related to an adaptive humoral response rather than $\mathrm{NAb}$.

\section{Immunoglobulins in the Mammary Gland}

The lactation period in cows has been extended through artificial selection by humans. However, even if milk's original purpose of exclusively feeding the calf has been modified, the mechanisms of antibody synthesis or transportation to the udder should fundamentally remain the same. Associations found between the risk of mastitis and NAb (Thompson-Crispi et al., 2013) imply that NAb serve a dual purpose, both protecting the udder against infections and providing the calf with passive immunity.

Several known passageways for different molecules go into the mammary gland lumen, and it is possible that antibodies and plasma cells get transported through one or more of these (Baumrucker and Bruckmaier, 2014). Smaller immunoglobulins such as IgG and $\operatorname{IgA}$ get transported via transcytosis, and IgG may leak from serum through tight junctions. Plasma cells, on the other hand, could be transported via diapedesis. Evidence suggests that at least some of the $\operatorname{IgM}$ in milk might be produced directly in the udder; a transcriptome study found that one of our candidate genes, IGLL1, a fundamental gene for the pro-B stage in naïve $\mathrm{B}$ cells, is expressed in the mammary gland (Bionaz et al., 2012). Ultimately, the presence of antibodies in milk is likely the result of independent parallel mechanisms, including on-site secretion. This would explain why phenotypic correlations between antibodies in serum and milk are consistently lower than genetic correlations (the latter reflecting production of these antibodies by $\mathrm{B}$ cells regardless of their location; de Klerk et al., 2015; Denholm et al., 2018).

\section{Perspectives and Potential Applications}

Previous studies in cattle have shown relationships between NAb and health; however, it is not trivial to determine whether higher or lower levels of $\mathrm{NAb}$ are desirable, as it appears to vary depending on the trait. Longevity, for example, is negatively correlated with NAb in milk, and high levels of KLH-IgM in milk before parturition is a risk factor for negative energy balance (de Klerk, 2016); LPS and KLH NAb in milk have positive genetic correlations with lameness episodes (Denholm et al., 2018). On the other hand, lower risk of mastitis has been genetically correlated with higher levels of serum KLH-IgM (Thompson-Crispi et al., 2013), and postpartum uterine health has been associated with higher levels of KLH-IgG (Machado et al., 2014). These results might seem contradictory, but it appears that problems related to metabolic health or nutrition have a positive association with NAb levels, whereas infectious diseases have a negative association. Further studies are needed to understand the complex relationships between disease traits and NAb in dairy cattle.

Our results show that we can pinpoint variations in the genome that influence NAb and confirmed results from other studies (Jonsson et al., 2017; de Klerk et al., 2018). Some of the identified regions contain candidate genes that have a clear relationship with immunoglobulin production. Selection based on immune response traits has already been implemented by some dairy cattle breeding companies (Mallard et al., 2015). However, in the case of NAb, a better understanding of their relationships with diseases is needed before they can be applied as health indicators or in genomic selection.

\section{CONCLUSIONS}

Natural antibodies in milk have an important genetic component, and we identified specific variants in the genome that influence NAb. Candidate regions for IgM traits point toward immunoglobulin structural genes and early B cell development, which plays a crucial role in the $\mathrm{B}$ cell repertoire. As for $\mathrm{IgG}_{1}$ traits, the associated genes appear to be related to class switching involving T-helper cells, hinting that the observed effects might be part of an adaptive response. Our results provide new insights into the regulation of milk NAb that will help unravel the complex relationship between milk immunoglobulins and disease resistance in dairy cattle. A better understanding of these relationships is needed before milk NAb can be used as a biomarker for management or as a selection criterion.

\section{ACKNOWLEDGMENTS}

The data used in this study were collected as part of the Dutch Milk Genomics Initiative, funded by Wageningen University, NZO (Dutch Dairy Association, Zoetermeer, the Netherlands), Cooperative Cattle Improvement organization CRV (Arnhem, the Netherlands), and the Dutch technology foundation STW (Utrecht, the Netherlands). The first author currently benefits from a joint grant from the European Commission and the Swedish farmers' foundation for agricultural research (Stiftelsen Lantbruksforskning, Stockholm, Sweden) within the framework of the Erasmus Mundus joint doctorate "EGS-ABG" and from a partial scholarship from Programa de Innovación y Capital Humano para la Competitividad del Ministerio de Ciencia, Tecnología y Telecomunicaciones (PINNMICITT, San Jose, Costa Rica). 


\section{REFERENCES}

Almqvist, N., and I.-L. Mårtensson. 2012. The pre-B cell receptor; Selecting for or against autoreactivity. Scand. J. Immunol. 76:256262. https://doi.org/10.1111/j.1365-3083.2012.02751.x.

Avrameas, S. 1991. Natural autoantibodies: From "horror autotoxicus" to "gnothi seauton." Immunol. Today 12:154-159. https://doi.org/ 10.1016/S0167-5699(05)80045-3.

Baumgarth, N., J. W. Tung, and L. A. Herzenberg. 2005. Inherent specificities in natural antibodies: A key to immune defense against pathogen invasion. Springer Semin. Immunopathol. 26:347-362. https://doi.org/10.1007/s00281-004-0182-2.

Baumrucker, C. R., and R. M. Bruckmaier. 2014. Colostrogenesis: $\mathrm{IgG}_{1}$ transcytosis mechanisms. J. Mammary Gland Biol. Neoplasia 19:103-117. https://doi.org/10.1007/s10911-013-9313-5.

Berghof, T. V. L., M. G. R. Matthijs, J. A. J. Arts, H. Bovenhuis, R. M. Dwars, J. J. van der Poel, M. H. P. W. Visker, and H. K. Parmentier. 2019. Selective breeding for high natural antibody level increases resistance to avian pathogenic Escherichia coli (APEC) in chickens. Dev. Comp. Immunol. 93:45-57. https://doi.org/10 .1016/j.dci.2018.12.007.

Bionaz, M., K. Periasamy, S. L. Rodriguez-Zas, W. L. Hurley, and J. J. Loor. 2012. A novel dynamic impact approach (DIA) for functional analysis of time-course omics studies: Validation using the bovine mammary transcriptome. PLoS One 7:e32455. https://doi .org/10.1371/journal.pone.0032455.

Blackburn, T. E., T. Santiago, and P. D. Burrows. 2017. FCRLA-A resident endoplasmic reticulum protein that associates with multiple immunoglobulin isotypes in B lineage cells. Curr. Top. Microbiol. Immunol. 408:47-65. https://doi.org/10.1007/82_2017_40.

Breuer, R., M. S. Becker, M. Brechmann, T. Mock, R. Arnold, and P. H. Krammer. 2014. The protein phosphatase $2 \mathrm{~A}$ regulatory subunit B56 $\gamma$ mediates suppression of T cell receptor (TCR)-induced

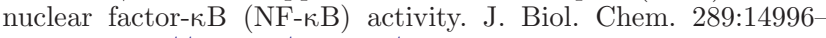
15004. https://doi.org/10.1074/jbc.M113.533547.

Calamito, M., M. M. Juntilla, M. Thomas, D. L. Northrup, J. Rathmell, M. J. Birnbaum, G. Koretzky, and D. Allman. 2010. Akt1 and Akt2 promote peripheral B-cell maturation and survival. Blood 115:4043-4050. https://doi.org/10.1182/blood-2009-09-241638.

Chen, J., J. J. Limon, C. Blanc, S. L. Peng, and D. A. Fruman. 2010 Foxo1 regulates marginal zone B-cell development. Eur. J. Immunol. 40:1890-1896. https://doi.org/10.1002/eji.200939817.

Cheng, Y.-S., O. Seibert, N. Klöting, A. Dietrich, K. Straßburger, S. Fernández-Veledo, J. J. Vendrell, A. Zorzano, M. Blüher, S. Herzig, M. Berriel Diaz, and A. A. Teleman. 2015. PPP2R5C couples hepatic glucose and lipid homeostasis. PLoS Genet. 11:e1005561. https://doi.org/10.1371/journal.pgen.1005561.

de Klerk, B. 2016. Antibodies and longevity of dairy cattle: Genetic analysis. PhD Thesis. Wageningen University, Wageningen, the Netherlands.

de Klerk, B., B. J. Ducro, H. C. M. Heuven, I. den Uyl, J. A. M. van Arendonk, H. K. Parmentier, and J. J. van der Poel. 2015. Phenotypic and genetic relationships of bovine natural antibodies binding keyhole limpet hemocyanin in plasma and milk. J. Dairy Sci. 98:2746-2752. https://doi.org/10.3168/jds.2014-8818.

de Klerk, B., M. Emam, K. A. Thompson-Crispi, M. Sargolzaei, J. J. van der Poel, and B. A. Mallard. 2018. A genome-wide association study for natural antibodies measured in blood of Canadian Holstein cows. BMC Genomics 19:694. https://doi.org/10.1186/ s12864-018-5062-6.

de Roos, A. P. W., B. J. Hayes, R. J. Spelman, and M. E. Goddard. 2008. Linkage disequilibrium and persistence of phase in HolsteinFriesian, Jersey and Angus cattle. Genetics 179:1503-1512. https: //doi.org/10.1534/genetics.107.084301.

Denholm, S. J., T. N. McNeilly, G. Banos, M. P. Coffey, G. C. Russell, A. Bagnall, M. C. Mitchell, and E. Wall. 2018. Immune-associated traits measured in milk of Holstein-Friesian cows as proxies for blood serum measurements. J. Dairy Sci. 101:10248-10258. https: //doi.org/10.3168/jds.2018-14825.

Duchemin, S. I., M. H. P. W. Visker, J. A. M. Van Arendonk, and H. Bovenhuis. 2014. A quantitative trait locus on Bos taurus auto- some 17 explains a large proportion of the genetic variation in de novo synthesized milk fatty acids. J. Dairy Sci. 97:7276-7285. https://doi.org/10.3168/jds.2014-8178.

Ekman, A., M. Ilves, and A. Iivanainen. 2012. B lymphopoiesis is characterized by pre-B cell marker gene expression in fetal cattle and declines in adults. Dev. Comp. Immunol. 37:39-49. https://doi .org/10.1016/j.dci.2011.12.009.

Erdenebayar, N., Y. Maekawa, J. Nishida, A. Kitamura, and K. Yasutomo. 2009. Protein-tyrosine phosphatase-kappa regulates CD4+ T cell development through ERK1/2-mediated signaling. Biochem. Biophys. Res. Commun. 390:489-493. https://doi.org/10.1016/j .bbrc.2009.09.117.

Fabregat, A., S. Jupe, L. Matthews, K. Sidiropoulos, M. Gillespie, P. Garapati, R. Haw, B. Jassal, F. Korninger, B. May, M. Milacic, C. D. Roca, K. Rothfels, C. Sevilla, V. Shamovsky, S. Shorser, T Varusai, G. Viteri, J. Weiser, G. Wu, L. Stein, H. Hermjakob, and P. D'Eustachio. 2018. The Reactome Pathway Knowledgebase. Nucleic Acids Res. 46:D649-D655. https://doi.org/10.1093/nar/ gkx1132.

Gilmour, A. R., B. J. Gogel, B. R. Cullis, S. J. Welham, and R. Thompson. 2015. ASReml User Guide. Release 4.1. VSN International, Hemel Hempstead, UK.

Hayes, B., and M. Goddard. 2010. Genome-wide association and genomic selection in animal breeding. Genome 53:876-883. https:// doi.org/10.1139/G10-076.

Heringstad, B., C. Egger-Danner, N. Charfeddine, J. E. Pryce, K. F. Stock, J. Kofler, A. M. Sogstad, M. Holzhauer, A. Fiedler, K. Müller, P. Nielsen, G. Thomas, N. Gengler, G. de Jong, C. Ødegård, F. Malchiodi, F. Miglior, M. Alsaaod, and J. B. Cole. 2018. Invited review: Genetics and claw health: Opportunities to enhance claw health by genetic selection. J. Dairy Sci. 101:4801-4821. https:// doi.org/10.3168/jds.2017-13531.

Herzog, S., and H. Jumaa. 2012. Self-recognition and clonal selection: Autoreactivity drives the generation of B cells. Curr. Opin. Immunol. 24:166-172. https://doi.org/10.1016/j.coi.2012.02.004.

Hogarth, P. M., and G. A. Pietersz. 2012. Fc receptor-targeted therapies for the treatment of inflammation, cancer and beyond. Nat. Rev. Drug Discov. 11:311-331. https://doi.org/10.1038/nrd2909.

Jabara, H. H., Y. Weng, T. Sannikova, and R. S. Geha. 2009. TRAF2 and TRAF3 independently mediate Ig class switching driven by CD40. Int. Immunol. 21:477-488. https://doi.org/10.1093/ intimm/dxp013.

Jonsson, S., G. Sveinbjornsson, A. L. de Lapuente Portilla, B. Swaminathan, R. Plomp, G. Dekkers, R. Ajore, M. Ali, A. E. H. Bentlage, E. Elmér, G. I. Eyjolfsson, S. A. Gudjonsson, U. Gullberg, A. Gylfason, B. V. Halldorsson, M. Hansson, H. Holm, Å. Johansson, E. Johnsson, A. Jonasdottir, B. R. Ludviksson, A. Oddsson, I. Olafsson, S. Olafsson, O. Sigurdardottir, A. Sigurdsson, L. Stefansdottir, G. Masson, P. Sulem, M. Wuhrer, A.-K. Wihlborg, G. Thorleifsson, D. F. Gudbjartsson, U. Thorsteinsdottir, G. Vidarsson, I. Jonsdottir, B. Nilsson, and K. Stefansson. 2017. Identification of sequence variants influencing immunoglobulin levels. Nat. Genet. 49:1182-1191. https://doi.org/10.1038/ng.3897.

Juntilla, M. M., J. A. Wofford, M. J Birnbaum, J. C. Rathmell, and G. A. Koretzky. 2007. Akt1 and Akt2 are required for alphabeta thymocyte survival and differentiation. Proc. Natl. Acad. Sci. USA 104:12105-12110. https://doi.org/10.1073/pnas.0705285104.

Kanehisa, M., M. Furumichi, M. Tanabe, Y. Sato, and K. Morishima. 2017. KEGG: New perspectives on genomes, pathways, diseases and drugs. Nucleic Acids Res. 45:D353-D361. https://doi.org/10 $.1093 / \mathrm{nar} / \mathrm{gkw} 1092$.

Khatkar, M. S., F. W. Nicholas, A. R. Collins, K. R. Zenger, J. A. L. Cavanagh, W. Barris, R. D. Schnabel, J. F. Taylor, and H. W. Raadsma. 2008. Extent of genome-wide linkage disequilibrium in Australian Holstein-Friesian cattle based on a high-density SNP panel. BMC Genomics 9:187. https://doi.org/10.1186/1471-2164 $-9-187$.

Liljavirta, J., M. Niku, T. Pessa-Morikawa, A. Ekman, and A. Iivanainen. 2014. Expansion of the preimmune antibody repertoire by junctional diversity in Bos taurus. PLoS One 9:e99808. https://doi .org/10.1371/journal.pone.0099808. 
Machado, V. S., M. L. S. Bicalho, R. O. Gilbert, and R. C. Bicalho. 2014. Short communication: Relationship between natural antibodies and postpartum uterine health in dairy cows. J. Dairy Sci. 97:7674-7678. https://doi.org/10.3168/jds.2014-8393.

Mallard, B. A., M. Emam, M. Paibomesai, K. Thompson-Crispi, and L. Wagter-Lesperance. 2015. Genetic selection of cattle for improved immunity and health. Jpn. J. Vet. Res. 63(Suppl. 1):S37S44. https://doi.org/10.14943/jjvr.63.suppl.s37.

Marnila, P., and H. Korhonen. 2011. Milk proteins - Immunoglobulins. Pages 807-815 in Encyclopedia of Dairy Sciences. 2nd ed. J. W. Fuquay, P. F. Fox, and P. L. H. McSweeney, ed. Academic Press, Wageningen, the Netherlands.

Melchers, F., E. ten Boekel, T. Seidl, X. C. Kong, T. Yamagami, K. Onishi, T. Shimizu, A. G. Rolink, and J. Andersson. 2000. Repertoire selection by pre-B-cell receptors and B-cell receptors, and genetic control of B-cell development from immature to mature B cells. Immunol. Rev. 175:33-46. https://doi.org/10.1034/j.1600 $-065 X .2000 .017510 . x$.

Mi, H., X. Huang, A. Muruganujan, H. Tang, C. Mills, D. Kang, and P. D. Thomas. 2017. PANTHER version 11: Expanded annotation data from Gene Ontology and Reactome pathways, and data analysis tool enhancements. Nucleic Acids Res. 45:D183-D189. https:/ /doi.org/10.1093/nar/gkw1138.

Moldt, B., and A. J. Hessell. 2014. Fc $\gamma$ Rs across species. Pages 145157 in Antibody Fc: Linking Adaptive and Innate Immunity. M. E. Ackerman and F. Nimmerjahn, ed. Academic Press, Oxford, UK.

Moore, C. R., Y. Liu, C. Shao, L. R. Covey, H. C. Morse, and P. Xie. 2012. Specific deletion of TRAF3 in B lymphocytes leads to Blymphoma development in mice. Leukemia 26:1122-1127. https:// doi.org/10.1038/leu.2011.309.

Mundt, C., S. Licence, T. Shimizu, F. Melchers, and I. L. Mårtensson. 2001. Loss of precursor B cell expansion but not allelic exclusion in VpreB1/VpreB2 double-deficient mice. J. Exp. Med. 193:435-445. https://doi.org/10.1084/jem.193.4.435.

NCBI Resource Coordinators. 2018. Database resources of the National Center for Biotechnology Information. Nucleic Acids Res. 46:D8-D13. https://doi.org/10.1093/nar/gkx1095.

Ploegaert, T. C., E. Tijhaar, T. J. Lam, A. Taverne-Thiele, J. J. van der Poel, J. A. van Arendonk, H. F. Savelkoul, and H. K. Parmentier. 2011. Natural antibodies in bovine milk and blood plasma: Variability among cows, repeatability within cows, and relation between milk and plasma titers. Vet. Immunol. Immunopathol. 144:88-94. https://doi.org/10.1016/j.vetimm.2011.07.008.

Ploegaert, T. C. W., S. Wijga, E. Tijhaar, J. J. van der Poel, T. J. G. M. Lam, H. F. J. Savelkoul, H. K. Parmentier, and J. M. van Arendonk. 2010. Genetic variation of natural antibodies in milk of Dutch Holstein-Friesian cows. J. Dairy Sci. 93:5467-5473. https:// doi.org/10.3168/jds.2010-3264.

Reshetnikova, E. S., L. V. Mechetina, O. Y. Volkova, S. V. Guselnikov, N. A. Chikaev, D. Kövesdi, B. Alabyev, G. Sármay, P. D. Burrows, A. M. Najakshin, and A. V. Taranin. 2012. Differential expression of FCRLA in naïve and activated mouse B cells. Cell. Immunol. 272:182-192. https://doi.org/10.1016/j.cellimm.2011.10.013.

Rosen, B., D. Bickhart, R. Schnabel, S. Koren, C. Elsik, A. Zimin, C. Dreischer, S. Schultheiss, R. Hall, S. Schroeder, C. Van Tassell, T. Smith, and J. Medrano. 2018. Modernizing the bovine reference genome assembly. Page 802 in Proc. World Congr. Genet. Appl. Livest. Prod. WCGALP, Auckland, New Zealand.

Schroeder, H. W., and L. Cavacini. 2010. Structure and function of immunoglobulins. J. Allergy Clin. Immunol. 125:S41-S52. https:/ /doi.org/10.1016/j.jaci.2009.09.046.

Slenter, D. N., M. Kutmon, K. Hanspers, A. Riutta, J. Windsor, N. Nunes, J. Mélius, E. Cirillo, S. L. Coort, D. Digles, F. Ehrhart, P. Giesbertz, M. Kalafati, M. Martens, R. Miller, K. Nishida, L. Rieswijk, A. Waagmeester, L. M. T. Eijssen, C. T. Evelo, A. R. Pico, and E. L. Willighagen. 2018. WikiPathways: A multifaceted pathway database bridging metabolomics to other omics research. Nucleic Acids Res. 46:D661-D667. https://doi.org/10.1093/nar/ gkx1064.

Spanopoulou, E., C. A. J. Roman, L. M. Corcoran, M. S. Schlissel, D. P. Silver, D. Nemazee, M. C. Nussenzweig, S. A. Shinton, R. R.
Hardy, and D. Baltimore. 1994. Functional immunoglobulin transgenes guide ordered B-cell differentiation in Rag-1-deficient mice. Genes Dev. 8:1030-1042. https://doi.org/10.1101/gad.8.9.1030.

Star, L., K. Frankena, B. Kemp, M. G. B. Nieuwland, and H. K. Parmentier. 2007. Natural humoral immune competence and survival in layers. Poult. Sci. 86:1090-1099. https://doi.org/10.1093/ps/86 .6.1090.

Stoop, W. M., J. A. M. van Arendonk, J. M. L. Heck, H. J. F. van Valenberg, and H. Bovenhuis. 2008. Genetic parameters for major milk fatty acids and milk production traits of Dutch HolsteinFriesians. J. Dairy Sci. 91:385-394. https://doi.org/10.3168/jds .2007-0181.

Storey, J. D., A. J. Bass, A. Dabney, and D. Robinson. 2015. qvalue: Q-value estimation for false discovery rate control. Accessed Aug. 27, 2019. https://www.bioconductor.org/packages/release/bioc/ html/qvalue.html.

Thompson-Crispi, K. A., F. Miglior, and B. A. Mallard. 2013. Genetic parameters for natural antibodies and associations with specific antibody and mastitis in Canadian Holsteins. J. Dairy Sci. 96:3965-3972. https://doi.org/10.3168/jds.2012-5919.

van Knegsel, A. T. M., G. de Vries Reilingh, S. Meulenberg, H. van den Brand, J. Dijkstra, B. Kemp, and H. K. Parmentier. 2007. Natural antibodies related to energy balance in early lactation dairy cows. J. Dairy Sci. 90:5490-5498. https://doi.org/10.3168/ jds.2007-0289.

Walsh, E. R., and S. Bolland. 2014. B cells: Development, differentiation, and regulation by $\mathrm{Fc} \gamma$ receptor IIB in the humoral immune response. Pages 115-129 in Antibody Fc: Linking Adaptive and Innate Immunity. M. E. Ackerman and F. Nimmerjahn, ed. Academic Press, Oxford, UK.

Wang, J., S. Vasaikar, Z. Shi, M. Greer, and B. Zhang. 2017. WebGestalt 2017: A more comprehensive, powerful, flexible and interactive gene set enrichment analysis toolkit. Nucleic Acids Res. 45:W130-W137. https://doi.org/10.1093/nar/gkx356.

Wijga, S., H. Bovenhuis, J. W. M. Bastiaansen, J. M. van Arendonk, T. C. W. Ploegaert, E. Tijhaar, and J. J. van der Poel. 2013. Genetic parameters for natural antibody isotype titers in milk of Dutch Holstein-Friesians. Anim. Genet. 44:485-492. https://doi .org/10.1111/age.12038.

Wilmink, J. B. M. 1987. Adjustment of test-day milk, fat and protein yield for age, season and stage of lactation. Livest. Prod. Sci. 16:335-348. https://doi.org/10.1016/0301-6226(87)90003-0.

Wilson, T. J., S. Gilfillan, and M. Colonna. 2010. Fc receptor-like A associates with intracellular IgG and IgM but is dispensable for antigen-specific immune responses. J. Immunol. 185:2960-2967. https://doi.org/10.4049/jimmunol.1001428.

Xie, P., Z. J. Kraus, L. L. Stunz, Y. Liu, and G. A. Bishop. 2011. TNF receptor-associated factor 3 is required for $\mathrm{T}$ cell-mediated immunity and TCR/CD28 signaling. J. Immunol. 186:143-155. https:// doi.org/10.4049/jimmunol.1000290.

Zerbino, D. R., P. Achuthan, W. Akanni, M. R. Amode, D. Barrell, J. Bhai, K. Billis, C. Cummins, A. Gall, C. G. Girón, L. Gil, L. Gordon, L. Haggerty, E. Haskell, T. Hourlier, O. G. Izuogu, S. H. Janacek, T. Juettemann, J. K. To, M. R. Laird, I. Lavidas, Z. Liu, J. E. Loveland, T. Maurel, W. McLaren, B. Moore, J. Mudge, D. N. Murphy, V. Newman, M. Nuhn, D. Ogeh, C. K. Ong, A. Parker, M. Patricio, H. S. Riat, H. Schuilenburg, D. Sheppard, H. Sparrow, K. Taylor, A. Thormann, A. Vullo, B. Walts, A. Zadissa, A. Frankish, S. E. Hunt, M. Kostadima, N. Langridge, F. J. Martin, M. Muffato, E. Perry, M. Ruffier, D. M. Staines, S. J. Trevanion, B. L. Aken, F. Cunningham, A. Yates, and P. Flicek. 2018. Ensembl 2018. Nucleic Acids Res. 46:D754-D761. https://doi.org/10 $.1093 / \mathrm{nar} / \mathrm{gkx} 1098$.

Zimin, A. V., A. L. Delcher, L. Florea, D. R. Kelley, M. C. Schatz, D. Puiu, F. Hanrahan, G. Pertea, C. P. Van Tassell, T. S. Sonstegard, G. Marcais, M. Roberts, P. Subramanian, J. A. Yorke, and S. L. Salzberg. 2009. A whole-genome assembly of the domestic cow, Bos taurus. Genome Biol. 10:R42. https://doi.org/10.1186/ gb-2009-10-4-r42. 